\title{
Metode Quality Function Deployment dan Fuzzy Topsis Untuk Sistem Pendukung Keputusan Pemilihan Perusahaan Penyedia Jasa Internet
}

\author{
Novianto Dwi Prasongko ${ }^{\mathrm{a} *}$, Rahmat Gernowo ${ }^{\mathrm{b}}$ \\ ${ }^{a}$ Magister Sistem Informasi, Program Pascasarjana, Universitas Diponegoro \\ bJurusan Fisika, Fakultas Sains dan Matematika, Universitas DIponegoro
}

Naskah Diterima : 23 Mei 2015; Diterima Publikasi : 13 November 2015

\begin{abstract}
Internet Service Provider (ISP) is a company or business organization that provides access to intenet and services related for individual consumer or companies. There are many ISP in Indonesia recently, and they have almost the same product to offered. This problem makes internet service provider selection become a major issue. Decision support system can be used to recommend the best ISP company based on need. The aim of this research is to used Quality Function Deployment with Fuzzy TOPSIS sequentially to select the best ISP company as needed, and implemented in decision support system for internet service provider selection. Quality Function Deployment and Fuzzy TOPSIS methods used to evaluate, and then recommend the ISP company by ranked. Quality Function Deployment method used to find out customers requirements about internet network, the weighting of the criteria and the assessment of each ISP company. Fuzzy TOPSIS used to rank ISP company. These two methods produce consistent ratings when sensitivity analysis is performed for fuzzy and crisp value. These two methods make decision support system result can be trusted.
\end{abstract}

Keywords : Quality Function Deployment; Fuzzy TOPSIS; Sensitivity Analysis

\begin{abstract}
Abstrak
Internet Service Provider (ISP) atau penyedia jasa internet merupakan perusahaan atau organisasi bisnis yang menyediakan akses intenet dan pelayanan yang berhubungan dengan dunia internet kepada konsumen perseorangan maupun perusahaan. Di Indonesia telah muncul banyak perusahan ISP dan semua menawarkan fasilitas yang hampir sama. Hal ini menyebabkan pemilihan perusahaan penyedia jasa internet merupakan masalah yang penting. Sistem pendukung keputusan dapat digunakan untuk merekomendasikan perusahaan ISP yang tepat. Penelitian ini bertujuan menggunakan metode Quality Function Deployment dengan Fuzzy TOPSIS secara berurutan untuk memilih perusahaan ISP terbaik sesuai kebutuhan, dan mengimplementasikannya pada sistem pendukung keputusan pemilihan perusahaan penyedia jasa internet. Metode Quality Function Deployment dan Fuzzy TOPSIS digunakan untuk mengevaluasi, kemudian merekomendasikan perusahaan ISP berdasarkan peringkat. Metode Quality Function Deployment digunakan untuk mencari tahu keinginan konsumen yang akan menggunakan jaringan internet, pembobotan kriteria dan penilaian setiap perusahaan ISP. Fuzzy TOPSIS digunakan untuk mencari peringkat setiap perusahaan ISP. Penggunaan kedua metode ini menghasilkan peringkat yang konsisten untuk nilai fuzzy dan nilai crisp saat dilakukan analisa sensitivitas sehingga menghasilkan sistem pendukung keputusan yang dapat dipercaya.
\end{abstract}

Kata kunci : Quality Function Deployment; Fuzzy TOPSIS; Analisa Sensitivitas

\section{Pendahuluan}

Internet Service Provider (ISP) atau penyedia jasa internet merupakan perusahaan atau organisasi bisnis yang menyediakan akses intenet dan pelayanan yang berhubungan dengan dunia internet kepada konsumen perseorangan maupun perusahaan (Rao, 2000). Di masa lalu, penyedia jasa internet (ISP) dikelola oleh perusahaan telepon. Namun sekarang, siapapun yang memiliki dana yang besar dan

*) Penulis korespondensi: sitechlip@gmail.com keahlian tentang dunia internet bisa memberikan jasa jaringan untuk mengakses internet. Di Indonesia telah muncul banyak perusahan ISP dan semua menawarkan fasilitas yang hampir sama. Hal ini menyebabkan pemilihan perusahaan penyedia jasa internet merupakan masalah yang penting (Amin dan Razmi, 2009).

Internet merupakan salah satu sumber informasi yang sangat berguna dan membantu karena data bisa didapatkan dari mana saja di seluruh dunia. Dalam 
dunia pendidikan, internet berguna untuk menopang proses belajar mengajar. Lebih spesifik lagi, di perguruan tinggi internet merupakan salah satu unsur yang harus ada dalam lingkungan kampus. Jaringan internet yang digunakan oleh perguruan tinggi tidak hanya terbatas pada akses untuk mendapatkan informasi, namun lebih dari itu internet juga berperan besar dalam operasional dan proses administratif di lingkungan kampus. Hal ini terjadi karena hampir semua perguruan tinggi di Indonesia sekarang telah menerapkan sistem online dalam perkuliahan dan proses administrasinya seperti proses pendaftaran mahasiswa baru, registrasi mahasiswa, pengisian KRS, melihat KHS, dll. Berdasarkan perkembangan tersebut, maka muncul permasalahan bagaimana memilih perusahaan penyedia jasa internet yang tepat untuk menopang kebutuhan sebuah universitas atau perguruan tinggi (Santoso, 2012).

Sistem pendukung keputusan dapat digunakan untuk merekomendasikan perusahaan ISP yang tepat untuk mendukung jaringan yang ada di lingkungan kampus perguruan tinggi. Sistem pendukung keputusan telah banyak digunakan terutama dalam mengatasi masalah pemilihan pemasok. Namun dalam perkembangannya, model yang digunakan dalam pemilihan pemasok juga dapat digunakakan untuk pemilihan perusahaan jasa. Perbedaan yang muncul antara pemilihan pemasok dan pemilihan perusahaan jasa terletak pada tidak dibutuhkannya biaya penyimpanan pada bidang jasa karena bukan materi yang ditawarkan oleh perusahaan jasa (Aissaoui et al., 2007).

Pemilihan pemasok dilakukan untuk memilih pemasok yang sesuai dengan kebutuhan perusahaan dan dengan biaya yang bisa diterima (Kahraman et al., 2003). Dalam proses pemilihan pemasok, beberapa pemasok yang ada di seleksi untuk mendapatkan pemasok yang paling tepat sesuai dengan kriteria-kriteria yang telah ditentukan. Sebagian besar penelitian tentang pemilihan pemasok dititik beratkan kepada pembelian produk mentah yang akan digunakan dalam proses produksi suatu barang di perusahaan (Aissaoui et al., 2007).

Pemilihan pemasok sangat penting karena dapat mempengaruhi biaya produksi yang berdampak kepada harga produk. Pemilihan pemasok merupakan masalah multi kriteria yang terdiri dari kriteria kualitatif dan kuantitatif. Fuzzy TOPSIS dan triangular fuuzy number digunakan untuk mengatasi masalah yang tidak pasti dalam pemilihan pemasok dan pemberian nilai yang tidak tepat oleh pengambil keputusan (Rouyendegh dan Saputro, 2014).

Banyak metode yang bisa digunakan untuk mengatasi masalah pemilihan pemasok, salah satunya fuzzy TOPSIS. Fuzzy TOPSIS digunakan untuk merekomendasikan pemasok yang terbaik berdasarkan bobot kriteria dan nilai dari tiap pemasok. Fuzzy TOPSIS cocok untuk diterapkan untuk mengatasi masalah pemilihan pamasok yang berhubungan dengan perubahan alternatif pilihan, kriteria, penambahan alternatif pilihan dan kriteria yang baru. Fuzzy TOPSIS menghasilkan peringkat yang lebih konsisten ketika alternatif pilihan dan kriteria yang baru ditambahkan ataupun diubah (Junior, 2014).

Quality Function Deployment (QFD) merupakan sebuah alat bantu strategis yang digunakan untuk membantu perusahaan dalam mengembangkan produk yang sesuai dengan keinginan konsumennya (Dursun dan Karsak, 2013). Namun dalam perkembangannya, QFD dapat diterapkan untuk sistem pendukung keputusan pemilihan pemasok. QFD digunakan untuk mendengarkan keinginan pemilik perusahaan, pemasok, operator pabrik dan konsumen. Dari data yang didapat diolah menggunakan AHP untuk merekomendasikan pemasok yang tepat (Scott et al., 2015).

Penilitan tentang pemilihan Internet Service Provider telah dilakukan sebelumnya untuk memilih dan mengevaluasi perusahaan ISP yang akan digunakan oleh hotel yang ada di tiga kota berbeda di negara Iran. Tujuan dari penelitian adalah memilih kriteria yang bisa digunakan untuk mengukur kinerja perusahaan ISP dan teknik apa yang harus dipilih bila kriteria kualitatif dan kuantitatif di pertimbangkan dalam proses manajemen ISP. Penelitian dilakukan dengan menggunakan metode QFD (Quality Function Deployment) meranking ISP berdasarkan kriteria kualitatif, kemudian model kuantitatif diadopsi untuk memperhitungkan matrik kuantitatif. Kemudian kedua model digabungkan untuk memilih ISP terbaik. Namun saat dilakukan analisa sensitivitas, muncul perbedaan peringkat dari ISP yang diteliti bila input menggunakan nilai fuzzy dan nilai crisp (Amin dan Razmi, 2009).

Dalam penelitian tentang pemilihan perusahaan ISP, QFD digunakan untuk mencari tahu keinginan konsumen yang akan menggunakan jaringan internet yang ditawarkan oleh perusahaan ISP. Dari data keinginan konsumen, kemudian dibangun House of Quality yang merupakan inti dari metode QFD. Pemberian peringkat dilakukan dengan menggunakan metode QFD untuk merekomendasikan perusahaan ISP yang dievaluasi. Namun muncul inkonsistensi pada peringkat yang dihasilkan menggunakan metodoe QFD saat dilakukan analisa sensitivitas (Amin dan Razmi, 2009).

Berdasarkan penelitian sebelumnya, maka dikembangkan model yang telah dibuat dengan menambahkan metode Fuzzy TOPSIS untuk menutupi kelemahan yang muncul dalam metode QFD dalam hal perankingannya. Perbedaanya dengan penelitian Amin dan Razmi terletak pada penambahan metode fuzzy TOPSIS untuk menghasilkan peringkat yang konsisten saat dilakukan analisa sensitivitas. Fuzzy TOPSIS dipilih karena metode TOPSIS jika digabungkan dengan intuitionistic fuzzy set memiliki peluang berhasil 
yang lebih besar untuk mengatasi masalah dalam multi-criteria decision-making karena terkadang terdapat ketidakpastian dalam pendapat yang diberikan oleh seorang pengambil keputusan (Boran et al., 2009). Fuzzy TOPSIS menghasilkan urutan peringkat yang lebih konsisten meskipun alternatif pilihan dan kriteria yang baru ditambahkan (Junior et al., 2014). Konsistensi peringkat yang dihasilkan oleh Fuzzy TOPSIS ini membuat peneliti menggabungkannya dengan metode Quality Function Deployment sehingga saat dilakukan analisa sentivitas menggunakan nilai fuzzy dan nilai crisp, peringkat perusahaan ISP tidak berubah. Selain itu variabel baru juga ditambahkan dalam menganalisa perusahaan ISP disesuaikan dengan kondisi yang ada di objek penelitian. Output sistem pendukung keputusan yang dihasilkan berupa peringkat perusahaan ISP yang lebih konsisten.

\section{Kerangka Teori}

\subsection{Triangular Fuzzy Number}

Dari beberapa macam bilangan fuzzy, Triangular Fuzzy Number (TFN) merupakan bilangan fuzzy yang paling sering digunakan. Triangular Fuzzy Number (TFN) merupakan bilangan fuzzy yang ditunjukkan dengan tiga titik: $\tilde{A}=(l, m, u)$ seperti terlihat di Gambar 1 (Rouyendegh dan Saputro, 2013). Triangular Fuzzy Number (TFN) dipilih karena kemudahan penggunaannya dalam proses penghitungan, selain itu pemodelan menggunakan Triangular Fuzzy Number (TFN) merupakan cara yang efektif untuk formulasi masalah keputusan dengan informasi yang tersedia subyektif dan tidak akurat (Rouhani et al., 2012).

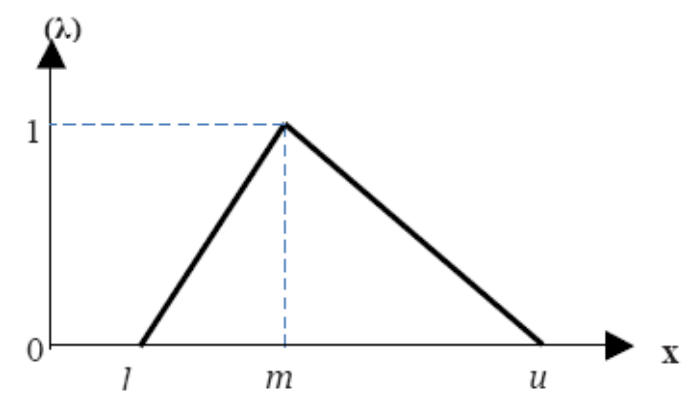

Gambar 1. Triangular Fuzzy Number

a) $l$ sampai $m$ merupakan fungsi penambahan

b) $m$ sampai $u$ merupakan fungsi pengurangan

c) $l \leq m \leq u$

$$
\mu_{A}(x)=\left\{\begin{array}{l}
0 \\
\frac{x-l}{m-l} \\
\frac{u-x}{u-m}
\end{array}\right.
$$

untuk $x<l ; x<u$

untuk $l \leq x \leq m$

untuk $m<x<u$
Ada beberapa operasi matematika dasar yang digunakan di dalam Triangular Fuzzy Number. Misal $\tilde{A}=(a, b, c), \tilde{E}=(d, e, f)$ merupakan Triangular Fuzzy Number, maka (Chou dan Chang, 2008; Klir dan Yuan, 1995):

(1) Operasi penjumlahan dua bilangan fuzzy

$\tilde{A} \oplus \tilde{E}=(a+d, b+e, c+f)$

(2) Operasi pengurangan dua bilangan fuzzy $\tilde{A} \nabla \tilde{E}=(a-d, b-e, c-f)$

(3) Operasi perkalian dua bilangan fuzzy $\tilde{A}(x) \tilde{E}=(a x d, b \times e, c \times f)$

(4) Operasi pembagian dua bilangan fuzzy $\tilde{A} \triangle \tilde{E}=\left(\frac{a}{d}, \frac{b}{e}, \frac{c}{f}\right)$

\subsection{Quality Function Deployment}

Mendengar dan mengerti keinginan konsumen merupakan konsep dasar dari QFD. Arsitektur dari QFD terdiri dari beberapa matrik yang sering disebut dengan House of Quality (HoQ). HoQ merupakan bagian pertama dari proses QFD. Bentuk dari HoQ bisa dilihat pada Gambar 2 (Chan dan Wu, 2002). Proses dari HoQ terdiri dari 6 bagian (Liu dan $\mathrm{Wu}$, 2008), yaitu:

1. Kebutuhan pelanggan (WHATs)

Perusahaan mengumpulkan informasi tentang apa yang diinginkan oleh pelanggan dari sebuah produk. WHATs ini merupakan kriteria dari sebuah kebutuhan.

2. Penilaian yang kompetitif

Bagian ini merupakan pemberian bobot terhadap seberapa penting kriteria yang telah didapat dari WHATs $\left(w_{i}\right)$.

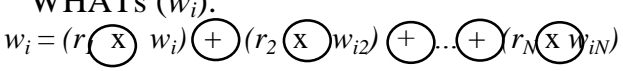

dimana $i=$ jumlah WHATs $(i=1,2, \ldots, i)$ dan $N=$ jumlah pengambil keputusan $(n=1,2, \ldots, N)$

3. Desain dari kebutuhan (HOWs)

Setelah perusahaan mengetahui harapan pelanggan yang dirangkum menjadi kriteriakriteria, maka perusahaan memikirkan bagaimana caranya memenuhi harapan pelanggan tersebut.

4. Matrik hubungan antara WHATs dan HOWs Membangun matrik hubungan antara harapan pelanggan (WHATs) dengan bagaimana cara perusahaan memenuhi harapan pelanggan tersebut. Setiap kriteria (WHATs) diberi bobot seberapa penting hubungannya dengan cara pemenuhan harapan tadi (HOWs).

$\left.a_{i j}=\left(r_{1} \bigcirc a_{i j l}\right) \oplus r_{2} \bigcirc a_{i j 2}\right) \odot \ldots \odot\left(r_{N} \bigcirc q_{i j N}\right)$

5. Matrik korelasinya

Pada bagian ini akan dianalaisa bagaimana pengaruh tiap HOWs terhadap supplier perusahaan.

6. Spesifikasi atau nilai target

Pada bagian ini dihitung bobot tiap supplier yang di dapat dari HOWs kemudian dikalikan dengan bobot kriteria (WHATs).

$f_{f}=\frac{1}{i} \bigcirc\left[\left(w_{l} \bigcirc a_{l j}\right) \odot \ldots \odot\left(w \bigcirc a_{i j}\right)\right]$ 


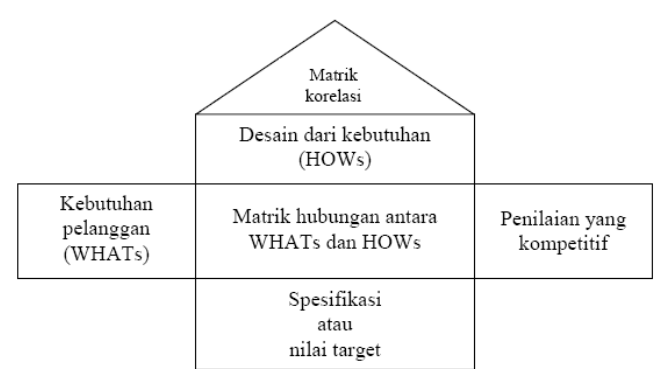

Gambar 2. House of quality (Chan dan Wu, 2002)

\subsection{Fuzzy TOPSIS}

Metode fuzzy TOPSIS diperkenalkan oleh Chen, pada tahun 2000 (Junior et al., 2014). Fuzzy TOPSIS ini digunakan untuk memecahkan masalah pengambilan keputusan dengan berbagai macam kriteria (MCDM) yang tidak pasti. Variabel linguistic dipakai oleh pengambil keputusan untuk memberi bobot pada kriteria dan nilai dari tiap alternatif, $D_{r}(r$ $=1, \ldots, k) . \widetilde{W}_{r}^{j}$ merupakan bobot dari kriteria $j$ yang diberikan oleh sejumlah pengambil keputusan $(r), C_{j}$ $(j=1, \ldots, m) . \tilde{x}_{j}^{r}$ merupakan nilai dari alternatif $i$ yang berhubungan dengan kriteria $j$ yang diberikan oleh sejumlah pengambil keputusan $(r)$. Prosedur dari metode fuzzy TOPSIS bisa kita bagi menjadi beberapa langkah sebagai berikut (Junior et al., 2014):

1. Kumpulkan bobot $\left(\widetilde{w}_{j}\right)$ dari tiap kriteria $\left(C_{j}\right)$ dan nilai $\left(\tilde{x}_{i j}\right)$ dari tiap alternatif $\left(A_{i}\right)$ berdasarkan kriteria $\left(C_{j}\right)$ yang diberikan oleh pengambil keputusan.

$$
\begin{aligned}
& \widetilde{w}_{j}=\frac{1}{k}\left[\widetilde{w}_{j}^{1}+\widetilde{w}_{j}^{2}+\ldots+\widetilde{w}_{j}^{k}\right] ; \mathrm{j}=1,2, \ldots, \mathrm{n} \\
& \tilde{x}_{i j}=\frac{1}{k}\left[\tilde{x}_{i j}^{1}+\tilde{x}_{i j}^{r}+\ldots+\tilde{x}_{i j}^{k}\right] \\
& \mathrm{i}=1,2, \ldots, \mathrm{m} ; \mathrm{j}=1,2, \ldots, \mathrm{n}
\end{aligned}
$$

2. Buat fuzzy matriks keputusan $\widetilde{D}$.

$$
\begin{aligned}
& \begin{array}{llll}
C_{1} & C_{2} & C_{j} & C_{n}
\end{array} \\
& \widetilde{D}=\begin{array}{c}
A_{1} \\
A_{2} \\
\vdots \\
A_{m}
\end{array}\left[\begin{array}{cccc}
\tilde{x}_{11} & \tilde{x}_{12} & \tilde{x}_{1 j} & \tilde{x}_{1 n} \\
\tilde{x}_{21} & \tilde{x}_{22} & \tilde{x}_{2 j} & \tilde{x}_{2 n} \\
\vdots & \vdots & \vdots & \vdots \\
\tilde{x}_{m 1} & \tilde{x}_{m 2} & \tilde{x}_{m j} & \tilde{x}_{m n}
\end{array}\right] \\
& \widetilde{W}=\left[\widetilde{w}_{1}+\widetilde{w}_{2}+\ldots+\widetilde{w}_{n}\right] \\
& \mathrm{i}=1,2, \ldots, \mathrm{m} ; \mathrm{j}=1,2, \ldots, \mathrm{n}
\end{aligned}
$$

3. Normalisasi fuzzy matriks keputusan kemudian diberi notasi $\tilde{R}$

$\tilde{R}=\left[\tilde{r}_{i j}\right]_{m \times n}, \mathrm{i}=1,2, \ldots, \mathrm{m} ; \mathrm{j}=1,2, \ldots, \mathrm{n}$

Rumus diatas bisa ditulis sebagai berikut:

$$
\tilde{r}_{i j}=\left(\frac{l_{i j}}{u_{j}^{*}}, \frac{m_{i j}}{u_{j}^{*}}, \frac{u_{i j}}{u_{j}^{*}}\right), u_{j}^{*}=\max _{i} u_{i j}
$$

4. Hitung bobot dari matriks keputusan yang telah dinormalisasi $(\tilde{V})$, dengan cara mengalikan bobot dari kriteria evaluasi $\left(\widetilde{w}_{\mathrm{j}}\right)$ dengan elemen $\tilde{r}_{i j}\left(\epsilon \tilde{r}_{i j}\right)$ dari fuzzy matriks keputusan yang telah dinormalisasi.

$$
\tilde{V}=\left[\tilde{v}_{i j}\right]_{m \times n}, \mathrm{i}=1,2, \ldots, \mathrm{m} ; \mathrm{j}=1,2, \ldots, \mathrm{n}
$$

dimana, $\tilde{v}_{i j}=\tilde{x}_{i j} \bigotimes \widetilde{v}_{\mathrm{j}}, \mathrm{i}=1,2, \ldots, \mathrm{m} ; \mathrm{j}=1,2, \ldots, \mathrm{n}$ (2.10)

5. Hitung fuzzy solusi ideal positif $\left(A^{+}\right)$dan fuzzy solusi ideal negatif $\left(A^{-}\right)$.

$$
\begin{gathered}
A^{+}=\left\{v_{1}^{+}, v_{j}^{+}, \ldots, v_{m}^{+}\right\} \\
A^{-}=\left\{v_{1}^{-}, v_{j}^{-}, \ldots, v_{m}^{-}\right\}
\end{gathered}
$$

dimana,

$v_{1}^{+}=(1,1,1)$ dan $v_{1}^{-}=(0,0,0)$

6. Hitung jarak dari tiap alternatif terhadap fuzzy solusi ideal positif $\left(d_{i}^{+}\right)$dan fuzzy solusi ideal negatif $\left(d_{i}^{-}\right)$menggunakan rumus berikut:

$$
\begin{aligned}
& d_{i}^{+}=\sum_{j=1}^{n} d_{v}\left(\tilde{v}_{i j}, v_{j}^{+}\right) \\
& d_{i}^{-}=\sum_{j=1}^{n} d_{v}\left(\tilde{v}_{i j}, v_{j}^{-}\right)
\end{aligned}
$$

Dimana $d(\ldots, \ldots)$ merupakan jarak antara dua angka fuzzy metode vertex. Dalam triangular fuzzy number persamaan nya sebagai berikut:

$$
d(\tilde{x}, \tilde{z})=\sqrt{\frac{1}{3}}\left[\left(l_{x}-l_{z}\right)^{2}+\left(m_{x}-m_{z}\right)^{2}+\left(u_{x}-u_{z}\right)^{2}\right]
$$

7. Hitung koefisien kedekatannya $\left(C C_{i}\right)$.

$$
C C_{i}=\frac{d_{i}^{-}}{d_{i}^{+}+d_{i}^{-}}
$$

Tentukan ranking dari tiap alternatif berdasarkan koefisien kedekatan $\left(C C_{i}\right)$ dalam urutan terbesar ke terkecil. Alternatif yang terbaik memiliki jarak terdekat kepada fuzzy solusi ideal positif dan jarak terjauh terhadap fuzzy solusi ideal negatif.

\section{Metodologi}

\subsection{Prosedur Penelitian}

Semua langkah-langkah yang akan dilakukan selama penelitian ini bisa dilihat dalam Gambar 3, kemudian akan dijabarkan lebih lanjut untuk setiap langkahnya.

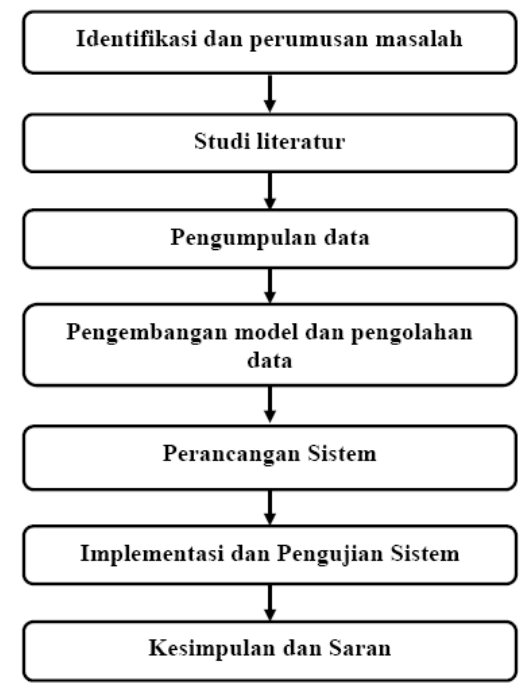

Gambar 3. Prosedur penelitian

Pada tahap ini dilakukan beberapa proses diantaranya Pengumpulan data dilakukan dengan cara melakukan wawancara kepada mahasiswa, dosen dan bagian administrasi tentang bagaimana 
kinerja jaringan internet yang sudah ada, dan apa yang diinginkan dari sebuah jaringan internet. Kemudian melakukan pengembangan model dan pengolahan data, analisis dan perancangan sistem, implementasi dan pengujian sistem, kemudian kesimpulan.

Bentuk dari tahap implementasi sistem adalah pembuatan aplikasi dengan metode QFD dan fuzzy TOPSIS untuk sistem pendukung keputusan pemilihan perusahaan ISP. Tahap terakhir dilakukan pengujian sistem apakah sistem dapat berjalan seperti yang diharapkan atau tidak. Pengujian dilakukan dalam bentuk dua tahap, yaitu pengujian terhadap performa sistem dan pengujian terhadap proses perhitungan analisa hasil uji terhadap aliran data yang digunakan.

\section{Hasil dan Pembahasan}

\subsection{Hasil Penelitian}

Untuk pemberian bobot kriteria dan nilai pada setiap perusahaan ISP digunakan skala linguistic seperti pada Tabel 1 dan Tabel 2 (Chen, 2000).

Tabel 1. Skala linguistic untuk bobot dari kriteria

\begin{tabular}{ll}
\hline $\begin{array}{l}\text { Nilai dalam skala } \\
\text { linguistic }\end{array}$ & $\begin{array}{l}\text { Triangular Fuzzy } \\
\text { Number }\end{array}$ \\
\hline $\begin{array}{l}\text { Sangat Tidak Penting } \\
\text { (STP) }\end{array}$ & $(0.0,0.0,0.25)$ \\
Tidak Penting (TP) & $(0.0,0.25,0.50)$ \\
Netral (N) & $(0.25,0.50,0.75)$ \\
Penting (P) & $(0.50,0.75,1.0)$ \\
Sangat Penting (SP) & $(0.75,1.0,1.0)$ \\
\hline
\end{tabular}

Tabel 2. Skala linguistic untuk nilai setiap perusahaan ISP

\begin{tabular}{ll}
\hline Nilai dalam skala & $\begin{array}{l}\text { Triangular Fuzzy } \\
\text { linguistic }\end{array}$ \\
\hline Sangat Rendah (SR) & $(0.0,0.0,2.5)$ \\
Rendah (R) & $(0.0,2.5,5.0)$ \\
Rata-Rata (RT) & $(2.5,5.0,7.5)$ \\
Tinggi (T) & $(5.0,7.5,10.0)$ \\
Sangat Tinggi (ST) & $(7.5,10.0,10.0)$ \\
\hline
\end{tabular}

Dari hasil wawancara yang dilakukan kepada mahasiswa, dosen dan bagian administrasi, maka dapat disimpulkan bahwa bagian WHATs dari House of Quality di dalam metode Quality Function Deployment adalah Aksesbilitas (C1), Kecepatan (C2), Stabilitas jaringan (C3), dan Keamanan (C4) sesuai dengan kriteria awal yang dilakukan saat studi literatur. Kemudian dilakukan wawancara kepada pengambil keputusan untuk memberi bobot kepada hasil dari WHATs tersebut, seperti terlihat di Tabel 3.
Pada proses pengambilan keputusan memberikan penilaian hubungan antara keinginan pengguna jaringan internet (WHATs) dengan respon teknis dari pengambil keputusan (HOWs). Hubungan yang terbentuk disebut matrik hubungan antara WHATs dan HOWs, yang tersaji di Tabel 4. Kemudian pengambil keputusan memberikan penilaian kepada setiap perusahaan ISP berdasarkan respon teknis (HOWs) seperti terlihat di Tabel 5.

Tabel 3. Tabel bobot kriteria WHATs

\begin{tabular}{cll}
\hline No & \multicolumn{1}{c}{ WHATs } & \multicolumn{1}{c}{ Bobot } \\
\hline 1 & Aksesbilitas & Sangat Penting \\
2 & Kecepatan & Sangat Penting \\
3 & Stabilitas Jaringan & Sangat Penting \\
4 & Keamanan & Sangat Penting \\
\hline
\end{tabular}

Dari data-data yang telah didapat, maka bisa dibangun sebuah House of Quality dari metode Quality Function Deployment, Tabel 6 menunjukkan House of Quality yang dibuat.

Dari HoQ metode Quality Function Deployment akan digunakan di metode fuzzy TOPSIS untuk mendapatkan peringkat dari tiap perusahaan ISP. Langkah pertama yang dilakukkan dalam metode fuzzy TOPSIS adalah membuat matriks keputusan yang telah dinormalisasi. Dari penilaian yang diberikan oleh pengambil keputusan kepada setiap perusahaan ISP harus di normalisasi triangular fuzzy number nya menggunakan persamaan 2.8.

Dari tabel nilai perusahaan ISP akan dihitung bobot fuzzy matrik keputusan ternormalisasi yang didapat dari hasil perkalian antara matrik keputusan ternormalisasi dengan bobot kriteria $\left(f_{1}-f_{6}\right)$ yang diperoleh dari HoQ. Untuk menghitung bobot fuzzy matrik keputusan ternormalisasi digunakan persamaan 2.9.

Setelah bobot fuzzy matrik keputusan ternormalisasi tersusun, maka kita harus menentukan fuzzy solusi ideal positif (FPIS) dan fuzzy solusi ideal negatif (FNIS). Di dalam metode fuzzy TOPSIS, nilai FNIS adalah nilai terkecil dari deret matrik tiap kriteria yang terbobot, dan nilai FPIS adalah nilai terbesar dari deret matrik tiap kriteria yang terbobot.

Langkah berikutnya dalam fuzzy TOPSIS adalah menghitung jarak antara dua angka fuzzy metode vertex terhadap fuzzy solusi ideal positif (FPIS) dan fuzzy solusi ideal negatif (FNIS) menggunakan persamaan 2.15. Setelah didapat jarak antara dua angka fuzzy terhadap fuzzy solusi ideal positif (FPIS) dan fuzzy solusi ideal negatif (FNIS) dari kriteriakriteria untuk setiap alternatif maka jumlahkan jarak antara dua angka fuzzy tersebut sehingga didapatkan jarak dari tiap alternatif terhadap fuzzy solusi ideal positif dan fuzzy solusi ideal negatif. 
Tabel 4. Matrik hubungan antara WHATs dan HOWs

\begin{tabular}{cccccccc}
\hline \multirow{2}{*}{ No } & \multirow{2}{*}{ WHATs } & Pengalaman & Legalitas & $\begin{array}{c}\text { Kekuatan } \\
\text { Finansial }\end{array}$ & $\begin{array}{c}\text { Dukungan } \\
\text { Teknis }\end{array}$ & Fasilitas & Biaya \\
\cline { 3 - 8 } & Aksesbilitas & Penting & Penting & Penting & Sangat Penting & $\begin{array}{c}\text { Sangat } \\
\text { Penting }\end{array}$ & Penting \\
& Kecepatan & Penting & Penting & Penting & Sangat Penting & $\begin{array}{c}\text { Sangat } \\
\text { Penting }\end{array}$ & Penting \\
& Stabilitas & Sangat & Penting & Sangat & Sangat Penting & Sangat & Penting \\
3 & jaringan & Penting & Penting & Panting & Penting \\
\hline
\end{tabular}

Tabel 5. Nilai setiap perusahaan ISP

\begin{tabular}{|c|c|c|c|c|c|c|c|}
\hline \multirow[b]{2}{*}{ No } & \multirow[b]{2}{*}{ Nama ISP } & \multicolumn{6}{|c|}{ HOWs } \\
\hline & & Pengalaman & Legalitas & $\begin{array}{l}\text { Kekuatan } \\
\text { Finansial }\end{array}$ & $\begin{array}{c}\text { Dukungan } \\
\text { Teknis }\end{array}$ & Fasilitas & Biaya \\
\hline 1 & Lintasarta & Sangat Tinggi & Tinggi & Tinggi & Tinggi & Rata-Rata & Rata-Rata \\
\hline 2 & ICON+ & Sangat Tinggi & Tinggi & Tinggi & Rata-Rata & Tinggi & Mahal \\
\hline 3 & Astinet & Sangat Tinggi & Tinggi & Tinggi & Rata-Rata & Tinggi & Mahal \\
\hline 4 & Cepatnet & Sangat Tinggi & Tinggi & Tinggi & Rata-Rata & Rata-Rata & Rata-Rata \\
\hline 5 & Desnet & Tinggi & Tinggi & Rata-Rata & Tinggi & $\begin{array}{l}\text { Sangat } \\
\text { Tinggi }\end{array}$ & Mahal \\
\hline 6 & Adau & Rata-Rata & Tinggi & Rata-Rata & $\begin{array}{l}\text { Sangat } \\
\text { Tinggi }\end{array}$ & $\begin{array}{l}\text { Sangat } \\
\text { Tinggi }\end{array}$ & Mahal \\
\hline
\end{tabular}

Tabel 6. House of quality

\begin{tabular}{cccccccc}
\hline $\mathbf{C}_{\mathbf{5}}$ & $\mathbf{C}_{\mathbf{6}}$ & $\mathbf{C}_{\mathbf{7}}$ & $\mathbf{C}_{\mathbf{8}}$ & $\mathbf{C}_{\mathbf{9}}$ & $\mathbf{C}_{\mathbf{1 0}}$ & & \\
\hline$(0.5,0.75,1)$ & $(0.5,0.75,1)$ & $(0.5,0.75,1)$ & $(0.75,1,1)$ & $(0.75,1,1)$ & $(0.5,0.75,1)$ & $\mathbf{C}_{\mathbf{1}}$ & $(0.75,1,1)$ \\
$(0.5,0.75,1)$ & $(0.5,0.75,1)$ & $(0.5,0.75,1)$ & $(0.75,1,1)$ & $(0.75,1,1)$ & $(0.5,0.75,1)$ & $\mathbf{C}_{\mathbf{2}}$ & $(0.75,1,1)$ \\
$(0.75,1,1)$ & $(0.5,0.75,1)$ & $(0.75,1,1)$ & $(0.75,1,1)$ & $(0.75,1,1)$ & $(0.5,0.75,1)$ & $\mathbf{C}_{\mathbf{3}}$ & $(0.75,1,1)$ \\
$(0.75,1,1)$ & $(0.75,1,1)$ & $(0.5,0.75,1)$ & $(0.75,1,1)$ & $(0.75,1,1)$ & $(0.5,0.75,1)$ & $\mathbf{C}_{\mathbf{4}}$ & $(0.75,1,1)$ \\
$\mathbf{f}_{\mathbf{1}}$ & $\mathbf{f}_{\mathbf{2}}$ & $\mathbf{f}_{\mathbf{3}}$ & $\mathbf{f}_{\mathbf{4}}$ & $\mathbf{f}_{\mathbf{5}}$ & $\mathbf{f}_{\mathbf{6}}$ & & \\
$(0.47,0.88,1)$ & $(0.42,0.81,1)$ & $(0.42,0.81,1)$ & $(0.56,1,1)$ & $(0.56,1,1)$ & $(0.38,0.75,1)$ & \\
\hline
\end{tabular}

Langkah terakhir dari metode fuzzy TOPSIS adalah menghitung koefisien kedekatan dari jarak tiap alternatif terhadap fuzzy solusi ideal negatif $\left(\boldsymbol{d}_{\boldsymbol{i}}^{+}\right)$ dengan jarak tiap alternatif terhadap fuzzy solusi ideal positif $\left(\boldsymbol{d}_{\boldsymbol{i}}^{-}\right)$menggunakan persamaan 2.16. Peringkat yang dihasilkan dari metode fuzzy TOPSIS dapat dilihat di Tabel 7

Tabel 7. Koefisien Kedekatan Perusahaan ISP

\begin{tabular}{|c|c|c|c|}
\hline No & Nama ISP & $\mathrm{CC}$ & Ranking \\
\hline 1 & Lintasarta & 0.5115 & 5 \\
\hline 2 & ICON+ & 0.5348 & 2 \\
\hline 3 & Astinet & 0.5348 & 2 \\
\hline 4 & Cepatnet & 0.4830 & 6 \\
\hline 5 & Desnet & 0.5401 & 1 \\
\hline 6 & Adau & 0.5313 & 4 \\
\hline
\end{tabular}

\subsection{Pembahasan}

Setelah dilakukan analisa sensitivitas untuk melihat konsistensi peringkat yang dihasilkan dari penggabungan metode QFD dengan fuzzy TOPSIS.
Nilai yang akan diolah diubah menjadi nilai crisp kemudian peringkatnya dibandingkan dengan nilai fuzzy. Nilai crisp dan nilai fuzzy diolah menggunakan metode QFD kemudian hasil peringkatnya dibandingkan, hasilnya terlihat di Tabel 8. Setelah itu nilai crisp dan nilai fuzzy diolah menggunakan metode Quality Function Deployment dan fuzzy TOPSIS kemudian hasil peringkatnya dibandingkan untuk melihat konsistensi peringkat yang dihasilkan, hasilnya terlihat di Tabel 9.

Tabel 8. Perbandingan Peringkat di metode QFD

\begin{tabular}{cccccc}
\hline \multirow{2}{*}{ No } & \multirow{2}{*}{ ISP } & \multicolumn{2}{c}{ Fuzzy } & \multicolumn{2}{c}{ Crisp } \\
\cline { 3 - 6 } & & Nilai & Ranking & Nilai & Ranking \\
\hline 1 & Lintasarta & 0.4896 & 5 & 0.4938 & 5 \\
2 & ICON+ & 0.8955 & 2 & 0.8889 & 3 \\
3 & Astinet & 0.8955 & 2 & 0.8889 & 3 \\
4 & Cepatnet & 0 & 6 & 0 & 6 \\
5 & Desnet & 1 & 1 & 1 & 1 \\
6 & Adau & 0.8508 & 4 & 0.9259 & 2 \\
\hline
\end{tabular}


Tabel 9. Perbandingan Peringkat di penggabungan

\begin{tabular}{llcccc}
\multicolumn{4}{c}{ Metode QFD dengan Fuzzy TOPSIS } \\
\hline \multirow{2}{*}{ No } & \multirow{2}{*}{ ISP } & \multicolumn{2}{c}{ Fuzzy } & \multicolumn{2}{c}{ Crisp } \\
\cline { 3 - 6 } & & Nilai & Ranking & Nilai & Ranking \\
& & & & & \\
\hline 1 & Lintasarta & 0.5115 & $\mathbf{5}$ & 0.5174 & $\mathbf{5}$ \\
2 & ICON+ & 0.5348 & $\mathbf{2}$ & 0.6427 & $\mathbf{2}$ \\
3 & Astinet & 0.5348 & $\mathbf{2}$ & 0.6427 & $\mathbf{2}$ \\
4 & Cepatnet & 0.4830 & $\mathbf{6}$ & 0.3643 & $\mathbf{6}$ \\
5 & Desnet & 0.5401 & $\mathbf{1}$ & 0.6729 & $\mathbf{1}$ \\
6 & Adau & 0.5313 & $\mathbf{4}$ & 0.6357 & $\mathbf{4}$ \\
\hline
\end{tabular}

Hasil yang ditunjukkan oleh Tabel 9 menunjukkan bahwa peringkat akhir yang diolah menggunakan gabungan metode QFD dan fuzzy TOPSIS memberikan peringkat yang sama dan tidak berubah untuk setiap perusahaan ISP meskipun nilai dari tiap perusahaan ISP berubah. Hal ini membuktikan bahwa penggabungan metode QFD dan fuzzy TOPSIS akan menghasilkan peringkat yang konsisten baik untuk nilai fuzzy dan nilai crisp sehingga tidak terjadi keraguan saat dilakukan analisa sensitivitas.

\subsection{Implementasi Sistem}

Aplikasi sistem dapat dijalankan oleh user melalui browser. Tampilan web dapat dilihat pada Gambar 4.

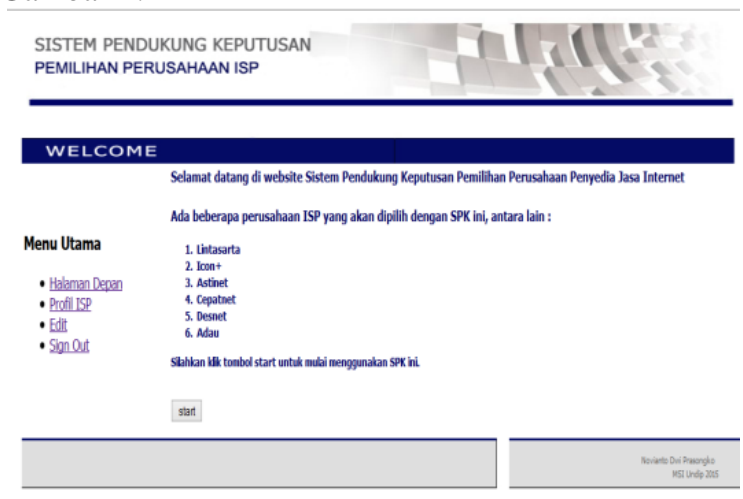

Gambar 4. Halaman utama

Sistem akan merekomendasikan perusahaan ISP berdasarkan peringkatnya. Tampilan hasil rekomendasi dari sistem dapat dilihat di Gambar 5.

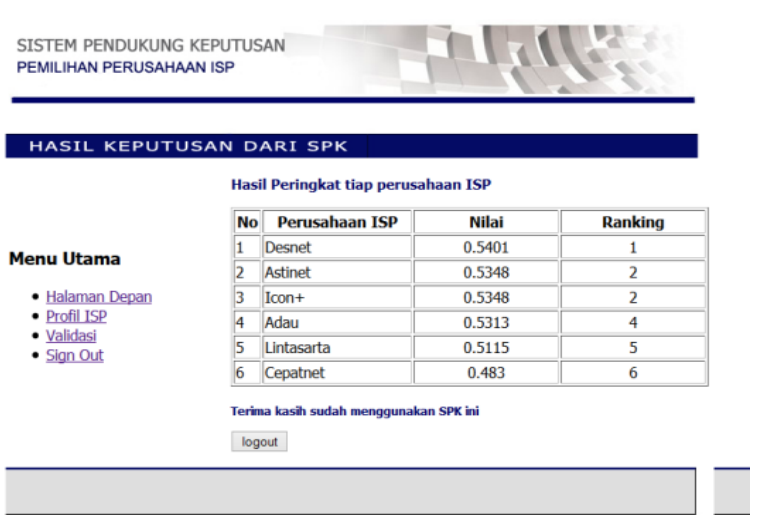

Gambar 5. Halaman peringkat ISP

\section{Kesimpulan}

Telah dibangun sistem pendukung keputusan untuk memilih perusahaan ISP. Sistem ini dibangun dengan menggunakan implementasi penggabungan dari metode QFD dan fuzzyTOPSIS.

Penggabungan metode QFD dan fuzzy TOPSIS menghasilkan peringkat yang konsisten saat dilakukan analisa sensitivitas dengan menggunakan nilai crisp dan nilai fuzzy.

\section{Daftar Pustaka}

Aissaoui, N., Haouari, M. and Hassini, E., 2007. Supplier selection and order lot sizing modeling: A Review, Computers and Operations Research 34 (12), 3516-3540.

Amin, S.H., and Razmi, J., 2009. An integrated fuzzy model for supplier management: a case study of isp selection and evaluation. Expert Systems with Applications, 36, 8639-8648.

Boran, F.E, Genc, S., Kurt, M. and Akay, D., 2009. A multi-criteria intuitionistic fuzzy group decision making for supplier selection with TOPSIS method. Expert Systems with Applications 36, 11363-11368.

Chan, L.K., and Wu, M.L., 2002. Quality function deployment: a literature review. European Journal of Operational Research, 143, 463-497.

Chen, C.T., 2000. Extensions of the TOPSIS for group decision-making under fuzzy environment. Fuzzy Sets Syst, 114, 1-9. 
Chou, S.Y., and Chang, Y.H., 2008. A decision support system for supplier selection based on a strategy-aligned fuzzy SMART approach. Expert Systems with Applications 34(4), 2241-2253.

Dursun, M. and Karsak, E.E., 2013. A QFD-Based Fuzzy MCDM approach for supplier selection. Applied Mathematical Modelling, 37, 58645875.

Kahraman, C., Cebeci, U. and Ulukan, Z., 2003. Multi-criteria supplier selection using fuzzy AHP. Logistics Information Management, 16 (6), 382394.

Klir, G.J. and Yuan, B., 1995. Fuzzy Sets and Fuzzy Logic: Theory and Applications, Englewood Cliffs, Prentice-Hall, NJ.

Junior, L.F.R., Osiro, L., and Carpinetti, L.C.R., 2014. A Comparison between fuzzy AHP and fuzzy TOPSIS methods to supplier selection. Applied Soft Computing 21, 194-209.

Liu, C.H., and Wu, H.H., 2008. A fuzzy group decision-making method in the relationship between customer requirements and technical measures of quality function deployment.
The International Journal of Industrial Engineering: Theory, Applications and Practice, 15 (2), 211-219.

Rao, S.S., 2000. Internet Service Providers in India, Work Study 49 (5), 178-186.

Rouhani, S., Mehdi, G., Mostafa, J., 2012. Evaluation model of business intelligence for enterprise system using fuzzy TOPSIS. Expert Systems with Applications 39, 3764-3771.

Rouyendegh, B.D., and Saputro, T.E., 2014. Supplier Selection Using Integrated Fuzzy TOPSIS and MCGP: A Case Study. Procedia - Social and Behavioral Sciences, 116, 3957 - 3970.

Santoso, H., 2012. Strategi Memilih Internet Service Provider Terbaik untuk Perguruan Tinggi (Studi Kasus: STIMIK Atma Luhur), Seminar Nasional Aplikasi Teknologi Informasi.

Scott, J., Ho, W., Dey, P.K., dan Talluri, S., 2015, A Decision support system for supplier selection and order allocation in stochastic, multistakeholder and multi-criteria environments. Int. J. Production Economics 166, 226-237 